\title{
TRANSEXUALIDADE NO STJ: DESAFIOS PARA A DESPATOLOGIZAÇÃO À LUZ DO DEBATE BUTLER-FRASER
}

TRANSEXUALIDAD EN EL STJ: RETOS PARA LA DESPATOLOGIZACIÓN A LA LUZ DEL DEBATE BUTLER-FRASER

TRANSEXUALIDAD EN EL STJ: RETOS PARA LA DESPATOLOGIZACIÓN A LA LUZ DEL DEBATE BUTLER-FRASER

Maria Eugenia Bunchaft ${ }^{1}$

1 Professora do Programa de Pós-Graduação em Direito da UNISINOS. Pós-Doutora em Filosofia pela UFSC. Doutora e Mestre em Teoria do Estado e Direito Constitucional pela PUC-Rio. Professora de Direito Constitucional da Graduação em Direito da UNISINOS. Orientadora de Mestrado. Autora do livro "Ativismo Judicial e minorias: Filosofia Constitucional do Reconhecimento. Curitiba: Juruá, 2014" e "Patriotismo Constitucional: Jürgen Habermas e a Reconstrução da Ideia de Nação na Filosofia Política Contemporânea. Curitiba: Juruá, 2015". mbunchaft@ig.com.br

Esse artigo é resultado da coordenação de dois projetos de pesquisa. O primeiro projeto é intitulado "Direitos fundamentais de grupos estigmatizados na jurisprudência do STJ, STF e Suprema Corte norteamericana à luz da filosofia do reconhecimento", financiado pela UNISINOS. O segundo projeto é relativo à coordenação do Projeto aprovado e financiado pela FAPERGS, intitulado "Judicialização, Deliberação e Minorias LGBT: uma reflexão sobre os contextos brasileiro e norteamericano", relativo ao Edital Pesquisador Gaúcho 02/ 2014. 
Resumo: Este artigo analisa os direitos de transexuais na jurisprudência do Superior Tribunal de Justiça (STJ) à luz do debate Butler-Fraser. O debate Butler-Fraser é fundamental para a compreensão da discussão sobre os direitos fundamentais de transexuais, expressa no julgamento do Recurso Especial n. 1.008.398-SP, elucidando a estratégia argumentativa implícita no voto da Ministra Nancy Andrigui que, embora seja um passo na trajetória da despatologização na jurisprudência brasileira, ainda mantém o binarismo de gênero como uma estrutura teórica de decisão.

Palavras-chave: Transexualidade. Reconhecimento. Gênero. Butler. Fraser.

Abstract: This essay analyzes the rights of transsexual people in the jurisprudence of the Superior Court of Justice, in light of the Butler-Fraser debate. This debate is fundamental to understanding the discussion of the fundamental rights of transsexuals expressed in the judgment of Special Appeal n. 1.008.398-SP, elucidating the argumentation strategy implicit in the vote of Minister Nancy Andrigui which, although it is a step on the path to depathologization in Brazilian jurisprudence, still maintains gender binarism as a theoretical framework for decision-making.

Keywords: Transsexuality. Recognition. Gender. Butler. Fraser.

Resumen: Este artículo analiza los derechos de los transexuales en la jurisprudencia del Superior Tribunal de Justicia (STJ) a la luz del debate Butler-Fraser. El debate Butler-Fraser es fundamental para la comprensión de la discusión sobre los derechos fundamentales de los transexuales, expresada en el juzgamiento del Recurso Especial n. 1.008.398-SP, elucidando la estrategia argumentativa implícita en el voto de la Ministra Nancy Andrigui que, aunque sea un paso en la trayectoria de la despatologización en la jurisprudencia brasileña, todavía mantiene el binarismo de género como una estructura teórica de decisión.

Palabras clave: Transexualidad. Reconocimiento. Género. Butler. Fraser. 


\section{INTRODUÇÃO}

transexualidade é um dos temas mais controversos da bioética. A
temática é encoberta por autocompreensões assimétricas de mundo
vinculadasa uma moralidade tradicional religiosa as quais terminam por minimizar a necessidade de desconstrução do binarismo de gênero. Em face dessa interpretação, alguns tribunais têm partido de uma leitura moral do ordenamento jurídico e de uma perspectiva reconstrutiva, superando visões assimétricas de mundo. O objetivo geral do presente trabalho, portanto, se concentra em investigar a efetivação dos direitos fundamentais de transexuais na jurisprudência do Superior Tribunal de Justiça (STJ), à luz do debate Butler-Fraser.

Diante dessa estrutura conceitual, os estudos contemporâneos sobre sexualidade demonstram que a concepção binária de gênero do Ocidente e o alinhamento automático entre sexo anatômico e identidade sexual configuram categorias construídas culturalmente. A pluralidade de identidades de gênero, que não se enquadra no binarismo convencional, não pode ser utilizada como fundamento para a sua patologização, a qual potencializa estigmas e incrementa a discriminação.

Assim, a filosofia do reconhecimento de Nancy Fraser se desvela como essencial para a desconstrução da concepção binária de gênero. De outro lado, o livro Problemas de Gênero, de Judith Butler, traz uma contribuição teórica fundamental que reflete a "terceira onda" do Movimento Feminista. Butler sublinha que a identidade da mulher, sustentada pelo movimento feminista, assume uma dimensão excludente, posto que inexistem atributos sexuais humanos que sejam estáveis e permanentes. Ademais, analisa as identidades de gênero que se encontram submetidas a estruturas de poder - como gays, lésbicas e transgêneros. A ideia é questionar o binarismo de gênero.

Contudo, por que motivo se faz imprescindível a compreensão acerca do debate Butler-Fraser na análise da temática dos direitos de transexuais na jurisprudência do STJ? Recentes decisões judiciais do STJ na regulamentação do direito à mudança de prenome e de sexo por transexuais inspiram uma possível discussão 
sobre se o reconhecimento seria considerado como uma questão de paridade de participação - como pretende Fraser - ou se o binarismo pode ser desmantelado por meio de práticas desconstrutivas da performatividade, exclusivamente.

Por conseguinte, o objetivo geral do presente trabalho é investigar a temática da efetivação de direitos fundamentais de transexuais na jurisprudência do STJ especificamente, a temática do binarismo e da despatologização, à luz do debate Butler-Fraser. Em suma, com o relevante aporte dessa discussão, tencionase elucidar, no julgamento do Recurso Especial n. 1.008.398-SP, a estratégia argumentativa implícita ao voto da Ministra Nancy Andrigui - que, embora seja um passo no caminho da despatologização na jurisprudência brasileira, ainda consagra o binarismo de gênero como referencial teórico-conceitual. Tal estrutura binária, para Butler², deve ser suscetível à desconstrução, de forma a questionar a regra da heteronormatividade e seus efeitos potencialmente excludentes. Ao ensejo, serão analisados outros julgados, incluindo o pedido de Homologação das Sentenças Estrangeiras n. 01058, n. $002149^{3}$, n. $004179{ }^{4}$ e n. $002732^{5}$ e 0 RESP n. 1.043.004/RS à luz do referencial teórico proposto.

Incorporando-se à crítica de Fraser ${ }^{6}$, assume-se a hipótese segundo a qual, embora Butler ${ }^{7}$ apresente um relevante diagnóstico da opressão contra transexuais - e que permite elucidar o discurso implícito ao voto da Ministra Nancy Andrigui no julgamento do RESP n ${ }^{\circ}$ 1008398/SP ${ }^{8}$-, sua abordagem não é capaz de justificar a motivação da crítica. Nessa perspectiva, sustenta-se como segunda hipótese o pressuposto segundo o qual Fraser delineou uma abordagem que revela maior

2 BUTLER, Judith. Problemas de Gênero: Feminismo e Subversão da Identidade. Rio de Janeiro: Civilização Brasileira, 2003.

3 BRASIL. Superior Tribunal de Justiça. Presidência. Sentença Estrangeira n. 2149. Voto do Relator, Min. Barros Monteiro. Brasília-DF, j. em 01.08.2006b. Disponível em: <www.stj. gov.br>. Acesso em: 04.10.2009.

4 BRASIL. Superior Tribunal de Justiça. Sentença Estrangeira n. 4.179. Voto do Relator Min. César Asfor Rocha. Brasília-DF, j. em 07.04.2009a. Disponível em: <www.stj.gov.br>. Acesso em: 04.10.2009.

5 BRASIL. Superior Tribunal de Justiça. Sentença Estrangeira n. 002732. Voto do Relator Min. César Asfor Rocha. Brasília-DF, j. em 07.04.2009b. Disponível em: <www.stj.gov.br>. Acesso em: 4/10/2009.

6 FRASER, Nancy. Heterosexism, misrecognition and capitalism: a response to Judith Butler. New Left Review, London, n. 228, 1998, p. 140-149.

7 BUTLER, Judith. Merely Cultural. Social Text, 52-53 (1997b), p. 265-77.

8 BRASIL, Superior Tribunal de Justiça. Terceira turma. Recurso Especial 1.008.398/SP. Voto da Relatora, Ministra Nancy Andrighi. Brasília-DF, j. 15.10.2009. Disponível em: <www. stj.gov.br>. Acesso em: 04.10.2010. 
alcance teórico para compreender o discurso implícito da Ministra-Relatora no julgamento do RESP $n^{\circ} 1008398 /$ SP$^{9}$, porquanto se contrapõe ao binarismo de gênero sem anular a autonomia do sujeito, assumindo como objetivos a paridade de participação e um projeto democraticamente informado por meio de contrapúblicos subalternos.

Nesse aspecto, o referencial teórico de Fraser revela maior potencial democrático, pressupondo uma crítica ao binarismo sexual - que é situada e autorreflexiva - e permitindo interpretar o sentido do referido julgamento. Não obstante, defende-se que as teorias de Butler e Fraser se complementam, pois a primeira identifica corretamente o diagnóstico. Fraser, por sua vez, desenvolve uma teoria da democracia baseada na ideia de contrapúblicos subalternos.

Investiga-se, então como primeiro objetivo específico, que a estrutura conceitual de Butler é relevante para compreender a estratégia argumentativa implícita ao teor do voto do Ministro Barros Monteiro no julgamento da Sentença Estrangeira n.01058, já que a teórica relaciona as reivindicações de despatologização da transexualidade a uma demanda mais profunda pela despatologização do gênero.

De outro lado, assume-se como segundo objetivo específico a proposta de demonstrar que somente é possível superar a exclusão partindo-se do pressuposto de que atributos biológicos não representam uma base estável para fundamentar a identidade. Postula-se como terceiro objetivo específico, com base na pesquisa de Bento e Pelúcio ${ }^{10}$, a inconsistência do argumento segundo o qual transexuais são possíveis suicidas e necessitam de um protocolo rígido baseado no laudo psiquiátrico como forma de "protegê-los de seus desejos".

Para tanto, o trabalho será estruturado pelo método fenomenológicohermenêutico, o qual pretende a aproximação entre sujeito e objeto a ser pesquisado. Não se trata de uma análise externa, como se o sujeito e o objeto estivessem desconectados, mas diferentemente, o sujeito está implicado diretamente, relacionando-se com seu objeto de estudo, interagindo com $9 \quad$ BRASIL, Superior Tribunal de Justiça. Terceira turma. Recurso Especial 1.008.398/SP. Voto da Relatora, Ministra Nancy Andrighi. Brasília-DF, j. 15.10.2009. Disponível em: <www. stj.gov.br>. Acesso em: 04.10.2010.

10 BENTO, Berenice e PELÚCIO, Larissa. Despatologização do gênero: a politização das identidades abjetas. Estudos Feministas, 20 (2), Florianópolis, 2012, p.569-581. 
ele e sofrendo os efeitos de seus resultados. Dessa feita, o pesquisador está inserido no mundo em que a pesquisa será realizada. No movimento do círculo hermenêutico, a pré-compreensão do pesquisador é anterior à sua compreensão e à sua interpretação, o qual atribuirá significado aos resultados da pesquisa. Adiciona-se também o método monográfico, tendo como técnica de pesquisa a investigação jurisprudencial de decisões no STJ sobre transexualidade.

\section{O DEBATE BUTLER-FRASER}

Butler ${ }^{11}$ resgata o pensamento de Foucault, especialmente no livro História da Sexualidade, o qual ressalta que o principal atributo da modernidade seria o controle político sobre o corpo, inspirando o fato de a conduta sexual ter assumido papel relevante a partir do momento em que a modernidade converte o crescimento populacional em uma questão política. Segundo Foucault, na modernidade há uma conexão entre ciência e poder, o que suscita uma fusão entre ambos. É no fim do século XVIII que surge uma tecnologia do sexo inteiramente nova, o que se reflete na clara assertiva de Foucault:

Nova, porque sem ser realmente independente da temática do pecado escapava, basicamente, à instituição eclesiástica. Através da pedagogia, da medicina e da economia, fazia do sexo não somente uma questão leiga, mas negócio de estado; ainda melhor, uma questão que todo o corpo social e quase cada um dos seus indivíduos eram convocados a porem-se em vigilância. Nova, também, porque se desenvolvia ao longo de três eixos: o da pedagogia, tendo como objetivo a sexualidade especifica da criança; o da medicina, com a fisiologia sexual própria das mulheres como objetivo; e, enfim, o da demografia, com o objetivo da regulação espontânea ou planejada dos nascimentos. ${ }^{12}$

Nesse panorama, surge a tecnologia disciplinar, pois a técnica científica inspira padrões de conduta, tornando-se um ideal regulatório que estabelece o que é proibido ou é permitido, e que incide sobre o indivíduo e também o constitui. Butler ${ }^{13}$, com base em Foucault, enfatiza que a própria regra científica constrói a 11 BUTLER, Judith. Problemas de Gênero: Feminismo e Subversão da Identidade. Rio de Janeiro: Civilização Brasileira, 2003.

12 FOUCAULT, Michel. História da Sexualidade. Rio de Janeiro: Paz \& Terra. 2015, p. 126-127.

13 BUTLER, Judith. Problemas de Gênero: Feminismo e Subversão da Identidade. Rio de Janeiro: Civilização Brasileira, 2003. 
identidade do sujeito, o que suscita um processo histórico que expressa uma luta pelo poder, no que se refere à prerrogativa de dizer o que está em consonância com a ciência. Como resultado, surge uma regra hegemônica que regula a construção de identidades. Nesse ponto, o sujeito é produzido pelo poder.

Butler $^{14}$ resgata tais reflexões para problematizar a dicotomia sexo/gênero estabelecida por Gayle Rubin ${ }^{15}$, assim como o binarismo de gênero. Propugna que a estratégia do feminismo seria problematizar a estabilidade e a universalidade da identidade de gênero, justamente porque resultam de relações de poder que estabelecem os grupos cujos interesses são contemplados pelo movimento feminista, incitando processos de exclusão.

Destarte, somente é possível superar a exclusão pressupondo que os atributos biológicos não são uma base coerente para fundamentar a identidade. Para Butler, tanto sexo como gênero sintetizam construções socioculturais que decorrem da pretensão dos sujeitos de se ajustarem às normas sociais. E é precisamente nesse aspecto que Butler defende que o gênero é performativo no sentido de ser estabelecido por formas de agir vinculadas à feminilidade e à masculinidade. As identidades de gênero são construídas por meio da linguagem, porquanto não há identidade de gênero que preceda à linguagem: a linguagem constrói o gênero.

Em Problemas de Gênero, Butler define o gênero como a estilização repetida do corpo, uma série de atos repetidos que se estabelecem coletivamente como expressões da identidade de gênero. Trata-se de uma sucessão de "atos, gestos e desejo que produzem o efeito de um núcleo ou substância interna, mas o produzem na superfície do corpo, por meio do jogo de ausências significantes, que sugerem, mas nunca revelam o princípio organizador da identidade como causa."16 Esses atos, gestos e atuações são performativos, pois "a essência ou identidade que, por outro lado, pretendem expressar são fabricações manufaturadas e sustentadas por signos corpóreos e outros meios discursivos." ${ }^{\text {17 }}$

14 BUTLER, Judith. Problemas de Gênero: Feminismo e Subversão da Identidade. Rio de Janeiro: Civilização Brasileira, 2003.

15 RUBIN, Gayle. Notes for a Radical Theory of the Politics of Sexuality. In: VANCE, Carol. Pleasure and Danger: Exploring female sexuality. Boston: Routledge \& K. Paul, 1984.

16 BUTLER, Judith. Problemas de Gênero: Feminismo e Subversão da Identidade. Rio de Janeiro: Civilização Brasileira, 2015, p. 235.

17 BUTLER, Judith. Problemas de Gênero: Feminismo e Subversão da Identidade. Rio de 
Para Butler, se a regra disciplinar da identidade de gênero estabelece que o desejo sexual do homem pela mulher é a base da identidade masculina e feminina, a reprodução da performance da heteronormatividade tem como efeito o ocultamento da dimensão política da regra disciplinar. Ao ser cotidianamente repetida, alcança o status de natural e de universal. A regra disciplinar atribui um caráter ilusório a uma essência feminina ou masculina como fundamento que irá pautar as condutas do homem e da mulher. ${ }^{18}$

Beltran aduz que a concepção de gênero como repetição associada à noção de sujeito como um efeito do poder "[...] permite a Butler desvincular o gênero da natureza-cultura e articulá-lo como mutável." ${ }^{19}$ Para arrematar a ideia, ainda conclui que "Essa estratégia também permite evitar a controvérsia sobre a construção e deixar uma porta aberta à possibilidade de mudança, enquanto que, ao mesmo tempo, consegue evitar a visão liberal do indivíduo como fonte de agência." 20

Consequentemente, Butler ${ }^{21}$ identifica como o âmbito da desconstrução de femininos e masculinos naturais a própria performance do sujeito, que deverá desvincular a adequação entre desejo, sexo e gênero. Um exemplo de resistência subversiva é a performance da regra da feminilidade realizada pelas Drag Queens. De acordo com Chambouleyron ${ }^{22}$, estas reproduzem ofeminino demodo estereotipado, de forma que a performance da regra da feminilidade é concretizada por um corpo masculino, do ponto de vista anatômico. Além do mais, subvertem publicamente a correspondência entre sexo, sexualidade e gênero, explicitando o caráter ilusório da essência feminina e masculina. Desconstruída essa ficção, surge a possibilidade de se contrapor à regra disciplinar fundamental e seus efeitos excludentes, revelando

Janeiro: Civilização Brasileira, 2015, p. 235.

18 BUTLER, Judith. Problemas de Gênero: Feminismo e Subversão da Identidade. Rio de Janeiro: Civilização Brasileira, 2015.

19 BELTRAN, Soley. Transexualidad y la Matriz Heterosexual: un Estudio Critico de Judith Butler. Barcelona: Belaterra, 2009, p. 47.

20 BELTRAN, Soley. Transexualidad y la Matriz Heterosexual: un Estudio Critico de Judith Butler. Barcelona: Belaterra, 2009, p. 47.

21 BUTLER, Judith. Problemas de Gênero: Feminismo e Subversão da Identidade. Rio de Janeiro: Civilização Brasileira, 2015.

22 CHAMBOULEYROUN, Ingrid Cyfer. A tensão entre Modernidade e Pós-modernidade na Crítica à Exclusão no Feminismo. Tese (Doutorado em Ciência Política) Faculdade de Filosofia, Letras e Ciências Humanas. Universidade de São Paulo, 2009, p. 29. 
as relações de poder que fundamentam a heteronormatividade e inspirando a possibilidade de os excluídos questionarem a regra disciplinar.

Trata-se assim de "[...] paródias de gênero que o revelam como uma ficção, um ideal inalcançável." ${ }^{23}$ Em relação às relações butch/femme, o objeto do desejo é a desestabilização da feminilidade que tem lugar no jogo erótico. Assim, ainda que as identidades butch e femme pressuponham a relação heterossexual, ao mesmo tempo a modificam, visto que "a repetição de construtos heterossexuais nas culturas sexuais gay e hétero bem pode representar o lugar inevitável da desnaturalização e mobilização das categorias de gênero. "24

Fraser $^{25}$ destaca que Butler sustenta uma ontologia pós-estruturalista do sujeito, em que não basta reconhecê-lo como construído por seu contexto, sendo necessário que ele seja reconhecido como produto do seu meio. Tal ideia não anula o potencial crítico do sujeito, mas a concepção de autonomia que integra uma estrutura de subjetividade prévia às estruturas de poder. A capacidade crítica em Butler seria marcada por alguns deficits importantes. Para Fraser ${ }^{26}$, não obstante Butler ${ }^{27}$ faça alusão à transformação social em seu aspecto positivo, seu raciocínio é insuscetível de teorizar critérios ou parâmetros para estabelecer a diferenciação entre a mudança progressista da conservadora e a opressora da emancipatória.

O instrumental foucaultiano faz com que a construção da identidade do sujeito inspire sua sujeição, impossibilitando resgatar uma dimensão de igualdade. Em outras palavras, "a desconstrução da identidade é boa porque é inclusiva" e "a reificação da identidade é ruim porque gera exclusão" e, segundo a concepção de Fraser, essa normatividade não atende aos desafios de uma teoria crítica feminista. ${ }^{28}$

23 BELTRAN, Soley. Transexualidad y la Matriz Heterosexual: un Estudio Critico de Judith Butler. Barcelona: Belaterra, 2009, p. 61.

24 BUTLER, Judith. Problemas de Gênero: Feminismo e Subversão da Identidade. Rio de Janeiro: Civilização Brasileira, 2015, p. 66.

25 FRASER, Nancy. Heterosexism, misrecognition and capitalism: a response to Judith Butler. New Left Review, London, n. 228, 1998, p. 140-149.

26 FRASER, Nancy. False Antitheses: a response to Seyla Benhabib and Judith Butler. In: FRASER, Nancy. Justice Interruptus: Critical Reflections on the Postsocialist Condition. Routledge: New York, 1997.

27 BUTLER, Judith. Problemas de Gênero: Feminismo e Subversão da Identidade. Rio de Janeiro: Civilização Brasileira, 2003.

28 FRASER, Nancy. False Antitheses: a response to Seyla Benhabib and Judith Butler. In: FRASER, Nancy. Justice Interruptus: Critical Reflections on the Postsocialist Condition. Routledge: New York, 1997. 
Outrossim, Butler ressalta que, para Foucault, os sujeitos participam do processo de construção de suas identidades não se reduzindo a superfícies passivas sobre as quais as regras atuam. Portanto, nos pressupostos de Butle ${ }^{29}$ e de Foucault ${ }^{30}$, a identidade é o produto da incidência da norma disciplinar sobre o sujeito e a sua participação na sua reprodução. O efeito é a subordinação por meio de um processo de encarceramento em papéis sociais que decorrem da auto-opressão. ${ }^{31}$

Se a autossubordinação então pressupõe a participação do sujeito, o que explica a auto-opressão? Para responder a essa indagação, é fundamental investigar a incidência do poder sobre o psiquismo humano e de que forma o poder é internalizado no universo psíquico, de maneira que nos engajamos na nossa própria submissão. Para analisar tal questão, Butler ${ }^{32}$ resgata o pensamento de Freud, especialmente os conceitos de melancolia e de perda constitutiva.

Em Luto e Melancolia, Freud ${ }^{33}$ diferencia os dois conceitos: enquanto o luto simboliza a reação a uma perda real, a melancolia é o sentimento no qual o melancólico, muitas vezes, não sabe o que efetivamente perdeu. Abrange assim uma condição patológica que se aproxima da depressão, o que implica a internalização do objeto perdido no ego. Butler ${ }^{34}$ utiliza a ideia freudiana de identificação regressiva para afirmar que as identidades - feminina e masculina - surgem a partir de proibições que determinam a perda de maneiras de viver a sexualidade. Salih, comentando a concepção de Freud e Butler, leciona que:

Enquanto Freud descreve a formação do ego como uma estrutura melancólica, pois o bebê é forçado a abandonar seus desejos por seus progenitores em reação ao tabu contra o incesto, Butler argumenta que o tabu contra o incesto é precedido pelo tabu contra a homossexualidade [...] Isso parece implicar que o desejo primitivo da criança é sempre o desejo pelo progenitor do mesmo sexo [...]. ${ }^{35}$

29 BUTLER, Judith. The Psychic Life of Power. Theories in Subjection.Standford, CA: Standford University Press, 1997a

30 FOUCAULT, Michel. História da Sexualidade. Rio de Janeiro: Paz \& Terra. 2015.

31 BUTLER, Judith. The Psychic Life of Power. Theories in Subjection.Standford, CA: Standford University Press, 1997a

32 BUTLER, Judith. Problemas de Gênero: Feminismo e Subversão da Identidade. Rio de Janeiro: Civilização Brasileira, 2003.

33 FREUD, Sigmund. Luto e Melancolia. São Paulo: Cosac Naify, 2011.

34 BUTLER, Judith. Problemas de Gênero: Feminismo e Subversão da Identidade. Rio de Janeiro: Civilização Brasileira, 2003.

35 SALIH, Sara. Judith Butler e a Teoria Queer. Belo Horizonte: Autêntica, 2012, p. 78-79. 
O objeto perdido é a homossexualidade, e o luto por essa perda é objeto de repressão. Segundo Butler, se as "[...] predisposições masculina e feminina são resultado da internalização efetiva desse tabu, e se a resposta melancólica à perda do objeto do mesmo sexo é incorporar e, a rigor, tornar-se esse objeto, por via da construção do ideal de ego", então a identidade de gênero parece ser, "[...] em primeiro lugar, a internalização de uma proibição que se mostra formadora da identidade. ${ }^{136} \mathrm{~A}$ estabilidade das identidades heterossexuais pressupõe a perda constitutiva da identidade de gênero.

A estabilidade da identidade de gênero também depende do cumprimento da regra da heterossexualidade e da aplicação coerente do tabu contra a homossexualidade. As identidades homossexuais não apenas violam a regra da heterossexualidade, mas também corroem as categorias de gênero, pois despertam a possibilidade de resgatar o objeto perdido.

É por isso que a regulação da identidade de gênero torna necessária a opressão da melancolia da homossexualidade. Para garantir uma identidade de gênero coerente, homens e mulheres devem negar o feminino e o masculino, respectivamente, o que instiga uma "predisposição" do desejo sexual. Segundo Butler, ser homem é desejar ter uma mulher, mas não ser uma mulher. A melancolia da homossexualidade não pode ser manifestada externamente - razão pela qual se volta contra o ego, na forma de superego. ${ }^{37}$

Butler ${ }^{38}$ cria uma conexão entre performance de gênero externalizada e melancolia, considerando a drag queen como exemplo de performance que questiona a suposta essência feminina autêntica. O preço da estabilidade das identidades minoritárias e das hegemônicas é a exclusão, e para superar esses processos de subordinação, a estratégia é expressar uma identidade incoerente - tal como o faz a drag queen. ${ }^{39}$

36 BUTLER, Judith. The Psychic Life of Power. Theories in Subjection.Standford, CA: Standford University Press, 1997a, p. 99.

37 BUTLER, Judith. Problemas de Gênero: Feminismo e Subversão da Identidade. Rio de Janeiro: Civilização Brasileira, 2003.

38 BUTLER, Judith. The Psychic Life of Power. Theories in Subjection.Standford, CA: Standford University Press, 1997a.

39 BUTLER, Judith. The Psychic Life of Power. Theories in Subjection.Standford, CA: Standford University Press, 1997a 
Butler $^{40}$ se contrapõe à justiça bidimensional de Fraser $^{41}$, argumentando que esta teria criado uma suposta dicotomia entre cultura e economia. Não seria assim possível considerar as demandas de gays e lésbicas como reivindicações meramente culturais, porquanto tais movimentos questionam também o funcionamento da economia política. Aponta ainda que Fraser ${ }^{42}$ minimiza o interesse econômico na regulação da heteronormatividade como pressuposto para a produção de uma população numerosa que satisfaça às demandas do capitalismo.

Butler ${ }^{43}$ resgata o pensamento do feminismo socialista da década de 1970 que afirma a importância da família como modo de produção -, advogando que a regulação heteronormativa da sexualidade é fundamental para o funcionamento da economia política e que lutas contra tal regulação ameaçam a viabilidade do sistema capitalista. Fraser ${ }^{44}$ contra-argumenta que esse raciocínio possui duas variantes: uma conceitual e outra funcionalista.

No primeiro aspecto, para Fraser ${ }^{45}$, Butler ${ }^{46}$ estaria minimizando a dimensão histórica da ideia de estrutura econômica e esvaziando sua força conceitual, e assim perderia de vista a compreensão da sociedade capitalista como forma de organização social distinta e particular. Ademais, confundiria a separação entre ordem econômica e de parentesco, entre a família e a vida pessoal, entre hierarquia de classe e status. Em suma, Butler ${ }^{47}$ estaria cega, ao pressupor a regulação sexual como parte da economia.

Na variante funcionalista, discorda que a regulação sexual seja funcional à expansão da mais-valia, uma vez que o sistema capitalista, para se manter, não necessita desse tipo de normatividade. O reconhecimento de gays, de lésbicas e de transexuais não dependeria da destruição do sistema capitalista, pois tais

40 BUTLER, Judith. Merely Cultural. Social Text, 52-53 (1997b), p. 265-77.

41 FRASER, Nancy. Heterosexism, misrecognition and capitalism: a response to Judith Butler. New Left Review, London, n. 228, 1998, p. 140-149.

42 BUTLER, Judith. Merely Cultural. Social Text, 52-53 (1997b), p. 265-77.

43 BUTLER, Judith. Merely Cultural. Social Text, 52-53 (1997b), p. 265-77.

44 FRASER, Nancy. Heterosexism, misrecognition and capitalism: a response to Judith Butler. New Left Review, London, n. 228, 1998, p. 140-149. 
identidades poderiam ser objeto de políticas voltadas para a reestruturação dos padrões de reconhecimento dentro do próprio sistema capitalista.

A produção e a reprodução dos sujeitos não podem partir de uma diferenciação entre ordem, cultura e economia. Na ótica de Butler ${ }^{48}$, a caracterização dos novos movimentos sociais como meras lutas no plano cultural tenderia a minimizar a discussão por distribuição e cultura. A questão não é verificar se as políticas sobre sexualidade dizem respeito à esfera cultural ou econômica, mas problematizar tal distinção. ${ }^{49}$ Fraser $^{50}$ contra-argumenta que, embora minorias sexuais sejam sujeitas à má distribuição, não são afetadas da mesma maneira que grupos que lutam fundamentalmente contra injustiça econômica.

Para Fraser ${ }^{51}$, a ideia de Butler de desconstrução da diferenciação entre reconhecimento e redistribuição implica perda da dimensão histórica indispensável para uma teoria social - porque estabelece a ação e a crítica social em atributos linguísticos como ressignificação e performatividade. O conceito de atos performativos de gênero se encontra deslocado do tempo e da história.

A historicização contempla uma perspectiva mais adequada de abordagem da teoria social, haja vista que permite analisar o caráter socioestrutural singular e historicamente específico da sociedade capitalista contemporânea. Permite identificar uma transformação social antissistêmica - que é insuscetível de ser concretizada por meio de uma "propriedade abstrata e trans-histórica" da linguagem, tal como ocorre com a ressignificação -, sendo necessário partir do caráter contraditório das relações sociais específicas.

Fraser confirma a centralidade da tensão nas relações sociais, diagnosticando as motivações das lutas. Em contraposição à ideia de que a regulação heteronormativa da sexualidade é econômica, sinaliza que a viabilidade do capitalismo contemporâneo independe do aumento populacional, ponderando que seria mais lógico atribuir às assimetrias econômicas de que sofrem gays e

48 BUTLER, Judith. Merely Cultural. Social Text, 52-53 (1997b), p. 265-77.

49 BUTLER, Judith. Merely Cultural. Social Text, 52-53 (1997b), p. 265-77.

50 FRASER, Nancy. Heterosexism, misrecognition and capitalism: a response to Judith Butler. New Left Review, London, n. 228, 1998, p. 140-149.

51 FRASER, Nancy. Heterosexism, misrecognition and capitalism: a response to Judith Butler.

New Left Review, London, n. 228, 1998, p. 140-149. 
lésbicas à ausência de reconhecimento. ${ }^{52}$ Posteriormente, em Scales of Justice, Fraser acrescentará a esfera "do político" como terceira dimensão da justiça. ${ }^{53}$

No ensaio Justice Social in the Age of Identity Politics, Fraser ${ }^{54}$ relata que todas as injustiças que afetam os grupos são bidimensionais, no entanto as mulheres e os grupos raciais são tipicamente bidimensionais, já que a má distribuição e o não reconhecimento incidem sobre tais com maior intensidade do que em relação a grupos de minorias sexuais ou a operários. Isso não implica que operários e gays não se submetam a injustiças econômicas e de não reconhecimento, mas somente que as classes são afetadas, sobretudo, por injustiças materiais; e os gays, por critérios culturais.

Diante da estrutura conceitual que se descortina, Fraser procura se distanciar de uma abordagem psicológica do reconhecimento, contrapondo-se à desvinculação entre as dimensões econômica e cultural e rompendo com a perspectiva dicotômica que privilegia as questões distributivas ou que se restringe às injustiças culturais. A divisão social entre homossexuais e heterossexuais, por exemplo, não se baseia apenas em critérios econômicos, tendo em vista que os homossexuais ocupam diferentes posições sociais na divisão do trabalho e não constituem uma classe especialmente explorada.

Destarte, em suas palavras, "[...] a divisão é enraizada, diferentemente, na ordem de status da sociedade como padrões institucionalizados de valores culturais que constroem a heterossexualidade como natural e normativa e a homossexualidade como perversa e desprezada." 55 Trata-se de padrões normativos institucionalizados nas diversas áreas do direito, relativas à família, à intimidade e à igualdade. É relevante também trazer que:

Eles estão também estabelecidos em muitas áreas da política governamental (incluindo imigração, naturalização e política de asilo)

52 FRASER, Nancy. Heterosexism, misrecognition and capitalism: a response to Judith Butler. New Left Review, London, n. 228, 1998, p. 140-149.

53 FRASER, NANCY. Scales of Justice: Reimagining political space in a globalizing world. New York: Columbia University Press, 2010.

54 FRASER, Nancy. Justice Social in the Age of Identity Politics. In: FRASER, Nancy; HON$\mathrm{NETH}$, Axel. Redistribution or Recognition? A Political Philosophical Exchange. London: Verso, 2003.

55 FRASER, Nancy. Justice Social in the Age of Identity Politics. In: FRASER, Nancy; HON$\mathrm{NETH}$, Axel. Redistribution or Recognition? A Political Philosophical Exchange. London: Verso, 2003, p. 18. 
e padrões de práticas profissionais (incluindo medicina e psicoterapia). Padrões valorativos heteronormativos também penetram na cultura popular e na interação cotidiana. $O$ resultado é construir gays e lésbicas como uma sexualidade desprezada, sujeitos a formas sexualmente específicas de subordinação de status. O último inclui vergonha e assalto, exclusão dos direitos e privilégios do casamento e parentesco, restrições nos direitos deexpressãoe eassociação, imagensestereotipadas danosas na mídia, assédio e depreciação na vida cotidiana e negação dos plenos direitos e de igual proteção da cidadania. ${ }^{56}$

Nesse sentido, gays e lésbicas sofrem uma série de injustiças como consequência da subordinação na ordem de status, considerando-se a institucionalização de normas heterossexistas que negam, por exemplo, a ampla gama de benefícios sociais e familiares concedidos às relações heterossexuais. Indubitavelmente, pode-se inferir que "[...] superar a homofobia e o heterossexismo exige a mudança da ordem sexual de status, desinstitucionalizando padrões valorativos heteronormativos e substituindo-os por padrões que expressem igual respeito por gays e lésbicas." ${ }^{15}$

Outrossim, em se tratando das classes sociais em que os indivíduos são tradicionalmente explorados, são necessários, entretanto, remédios redistributivos que visem superar injustiças econômicas. No caso das mulheres, a discriminação combina características de exploração econômica com elementos de discriminação sexual, de forma que a injustiça é tridimensional, situando-se tanto na esfera econômica, na esfera do reconhecimento, como no âmbito da representação.

Antes de tudo, é mister considerar que conglobam formas de injustiça primárias e co-originárias, de forma que "[...] nem uma política de redistribuição nem uma política de reconhecimento isoladamente são suficientes." ${ }^{158} \mathrm{As}$ mulheres necessitam combater ambas as dimensões da injustiça. A discriminação contra transexuais contempla uma categoria híbrida decorrente da injustiça econômica, da ordem

56 FRASER, Nancy. Justice Social in the Age of Identity Politics. In: FRASER, Nancy; HONNETH, Axel. Redistribution or Recognition? A Political Philosophical Exchange. London: Verso, 2003, p. 18.

57 FRASER, Nancy. Justice Social in the Age of Identity Politics. In: FRASER, Nancy; HONNETH, Axel. Redistribution or Recognition? A Political Philosophical Exchange. London: Verso, 2003, p. 19.

58 FRASER, Nancy. Justice Social in the Age of Identity Politics. In: FRASER, Nancy; HONNETH, Axel. Redistribution or Recognition? A Political Philosophical Exchange. London: Verso, 2003, p. 19. 
de status na sociedade e da esfera de representação, porque a orientação sexual estrutura a divisão fundamental entre trabalho produtivo remunerado - ocupado por heterossexuais - e trabalho mal remunerado, atribuído a travestis e a transexuais.

Sob esse aspecto, seria necessário combater a injusta divisão de trabalho que discrimina economicamente transexuais, assim como os padrões heterossexistas institucionalizados que incrementam o estigma. Esses padrões, pode-se dizer então, "[...] são relativamente independentes da economia política e não são meramente superestruturais. Eles, portanto, não podem ser superados apenas por redistribuição, mas exigem medidas adicionais independentes de reconhecimento." 59

A intensidade da medida adequada para solucionar a injustiça somente pode ser estabelecida empiricamente. Segundo Fraser, a essencialização da identidade é problemática e excludente, porque supõe a homogeneidade do grupo, sendo necessário que as políticas de reconhecimento se pautem pela desconstrução da identidade. Tal homogeneidade é opressora e estrategicamente inviável, já que obriga os indivíduos a se adequarem à cultura do grupo, minimizando a complexidade de filiações. ${ }^{60}$

As identidades são compreendidas como unidades estáticas e insuscetíveis a interações. Por fim, essa reificação oculta os conflitos de interesse que surgem no grupo e as desigualdades de poder na escolha da representação do grupo. Embora admita o reconhecimento das particularidades, este deve ser efetivado não em função da autenticidade, mas da igualdade de participação política. Considerar o reconhecimento como uma questão de status demanda conectálo à maneira como as instituições valoram a condição dos indivíduos como parceiros nas interações sociais.

Fraser discorda da crítica de Butler às teorias fundacionais da subjetividade e ressalta que a aliança entre teorias fundacionais da subjetividade e do imperialismo

59 FRASER, Nancy. Justice Social in the Age of Identity Politics. In: FRASER, Nancy; HON$\mathrm{NETH}$, Axel. Redistribution or Recognition? A Political Philosophical Exchange. London: Verso, 2003, p. 21.

60 FRASER, Nancy. Justice Social in the Age of Identity Politics. In: FRASER, Nancy; HON$\mathrm{NETH}$, Axel. Redistribution or Recognition? A Political Philosophical Exchange. London: Verso, 2003. 
cultural não decorre de uma necessidade conceitual, e sim, de circunstâncias históricas. Enfatiza ainda a utilização emancipatória das teorias fundacionais, como a Revolução Francesa ou a independência do Haiti. Em sua percepção, Butler estabeleceria falsas antíteses, como "[...] desreificação versus crítica normativa, desconstrução, versus reconstrução"61, aduzindo que o feminismo requer ambas, ou seja, "[...] a desconstrução e a reconstrução, a desestabilização do significado e a proteção da esperança utópica." ${ }^{\prime 2}$

Por conseguinte, Fraser ${ }^{63}$ ensina que o diagnóstico da falta de reconhecimento se dá por padrões institucionalizados de valores culturais que subordinam certos atores sociais. Como exemplos dessa subordinação, elencam-se o não reconhecimento entre pessoas do mesmo sexo e as políticas de bem-estar social que estigmatizam mães solteiras como sexualmente irresponsáveis - todos podem ser remediados por políticas de reconhecimento efetivadas não a partir de políticas da identidade, mas garantindo aos grupos estigmatizados a condição de parceiros plenos nas interações sociais.

\section{A TRANSEXUALIDADE: O DIREITO À SAÚDE E OS DESAFIOS DA DESPATOLOGIZAÇÃO À LUZ DA IDEIA DE CONTRAPÚBLICOS SUBALTERNOS}

Na verdade, haveria, para Fraser, uma multiplicidade de formas críticas de comunicação expressas em termos de "contrapúblicos", os quais constituem, pode-se referir, "[...] arenas discursivas paralelas nas quais os membros dos grupos socialmente subordinados inventam e circulam contradiscursos para formular interpretações opostas de suas identidades, interesses e necessidades." ${ }^{16}$

61 FRASER, Nancy. What's Critical about Critical Theory? In: MEEHAN, Johann (Ed.). Feminist Read Habermas: Gendering the Subject of Discourse. New York: Routledge, 1995, p. 71.

62 FRASER, Nancy. What's Critical about Critical Theory? In: MEEHAN, Johann (Ed.). Feminist Read Habermas: Gendering the Subject of Discourse. New York: Routledge, 1995, p. 71.

63 FRASER, Nancy. Justice Social in the Age of Identity Politics. In: FRASER, Nancy; HONNETH, Axel. Redistribution or Recognition?-A Political Philosophical Exchange. London: Verso, 2003.

64 FRASER, Nancy. Rethinking the Public Sphere: a Contribution to the Critique of Actually Existing Democracy. In: CALHOUN, Craig. Habermas and the Public Sphere. Cambridge: 
Indubitavelmente, de acordo com Fraser, como os membros dos grupos subordinados nem "[...] sempre teriam arenas para deliberar entre si próprios sobre suas necessidades, objetivos e estratégias" 65 , uma pluralidade de públicos concorrentes tem maior potencialidade em promover o princípio da paridade de participação - diferentemente de um público único, compreensivo. Nesse contexto, Fraser pretende demonstrar como, em processos discursivos da esfera pública, grupos sociais com desigualdade de poder assumem a perspectiva de desenvolver estilos culturais desigualmente valorados. ${ }^{66}$ Existem segmentos do movimento feminista que não concebem mulheres transexuais, como tais, ilustra as desigualdades nos processos discursivos da esfera pública oficial.

Nesse quadro teórico, conclui-se, com base nos pressupostos de Fraser, pela necessidade de desconstruir a dicotomia hetero-homo, desestabilizando as identidades sexuais, o que somente se efetivaria por meio da constatação de certos públicos alternativos que inspiram a circulação de discursos de oposição de grupos excluídos da esfera pública oficial (cujos exemplos são transexuais e travestis).

Essa multiplicidade de públicos concorrentes - especificamente no Brasil - proporcionou avanços relevantes nos debates sobre o direito à saúde de transexuais, por meio de acordos e de articulações entre o movimento social de transexuais e o Ministério da Saúde. Carvalho e Carrara ${ }^{67}$ asseveram que, desde 1997, houve o estabelecimento de um compromisso estratégico entre lideranças do Coletivo Nacional de Transexuais e segmentos progressistas do universo acadêmico. Nesse particular, essa aliança fomentou um conjunto de transformações nas políticas públicas de saúde voltadas para as demandas dos grupos transexuais, diferenciando-as dos grupos de travestis.

Mit Press, 1992, p. 123.

65 FRASER, Nancy. Rethinking the Public Sphere: a Contribution to the Critique of Actually Existing Democracy. In: CALHOUN, Craig. Habermas and the Public Sphere. Cambridge: Mit Press, 1992, p. 122-123.

66 FRASER, Nancy. Rethinking the Public Sphere: a Contribution to the Critique of Actually Existing Democracy. In: CALHOUN, Craig. Habermas and the Public Sphere. Cambridge: Mit Press, 1992.

67 CARVALHO, Mario Felipe Lima; CARRARA, Sérgio. Em direção a um futuro trans. Contribuições para a história do movimento de travestis e transexuais no Brasil. Sexualidad, Salud y Sociedad. Rio de Janeiro, n. 14, p. 319-351, 2013. Disponível em: <http://www.e-publicacoes.uerj.br/index.php/SexualidadSaludySociedad/article/view/6862/4940>. Acesso em: 05 set. 2014. 
Segundo Carvalho e Carrara, enquanto as organizações de travestis surgem do binômio "violência policial-AIDS", as organizações transexuais se articulam em torno de políticas de saúde voltadas para efetivar o acesso ao aparato biomédico que assegure o direito à cirurgia de transgenitalização, assim como em torno da possibilidade de modificação dos documentos.

No entanto, apesar de o discurso médico-psiquiátrico viabilizar a distinção da especificidade de suas demandas em relação às de travestis, muitas das lideranças do movimento transexual possuem suas identidades situadas em um universo próximo a este, especialmente no que se refere à prática da prostituição. De fato, travestis e transexuais são minorias sexuais não hegemônicas, cujas demandas e direitos, muitas vezes, são desconsiderados dentro do próprio Movimento Lésbicas, Gays, Bissexuais, Travestis, Transexuais e Transgêneros (LGBT).

Diante dessa leitura, a circulação de discursos de oposição de minorias sexuais não hegemônicas excluídas da esfera pública oficial - como transexuais e travestis - tem paulatinamente potencializado o princípio da paridade de participação delineado por Fraser, minimizando o deficit de liderança política de tais grupos. Paulatinamente, há maior protagonismo político das lideranças das Organizações Não Governamentais (ONGs) que representam grupos transexuais e travestis. Esse recente processo de amadurecimento político do movimento é incrementado por uma esfera pública transnacional estabelecida a partir da práxis discursiva de identidades trans que não se situam dentro das mesmas fronteiras de um Estado nacional.

Assim, de acordo com a Ação Global pela Igualdade Trans (GATE) e a Campanha Internacional Stop TransPathologization (STP), a Organização Mundial da Saúde (OMS) publicou uma nova proposta sobre saúde trans na versão da Classificação Internacional de Doenças (CID)-11, a qual contempla novas categorias reivindicadas pelo Grupo de Trabalho da OMS: incongruência de gênero na adolescência e idade adulta e incongruência de gênero na infância. Ambas as categorias integram um novo capítulo da CID-11: o Capítulo 06, que trata de condições relacionadas com a saúde sexual, separado do capítulo sobre transtornos mentais e de comportamento. 
Nesse sentido, a CID-11 será votada somente na Assembleia Mundial de Saúde no ano de 2017. Conforme preconizam a GATE e a STP, é preciso analisar e debater sobre a questão de a categoria "incongruência" poder repatologizar as questões trans na CID-11. A GATE e a STP defendem que o acesso à saúde e o reconhecimento da identidade de gênero configuram direitos humanos e que seu cumprimento não deve depender de categorias diagnósticas.

O protocolo dos centros de saúde que realizam a cirurgia incorpora discursos científicos e atribui aos transexuais uma identidade marcada por desordem psíquica, sem possibilidade de determinar, de maneira autônoma, suas identidades de gênero por meio de escolhas próprias em relação a seus corpos. Bento e Pelúcio pontuam que "[...] essa é uma estratégia discursiva que retira a autonomia e não reconhece a condição de sujeitos das pessoas transexuais e travestis." 68 Também em consonância com as perspectivas de Bento e Pelúcio, o gênero torna-se uma categoria medicalizável, sendo necessário utilizar instrumentos para curar suas anomalias. Logo,

Se partirmos do pressuposto de que há múltiplas possibilidades de experiências e práticas de gênero, e de que as pessoas que solicitam alterações corporais ou desejam migrar legalmente de um gênero imposto para outro com o qual se identificam são sujeitos, capazes de conferir sentido para essas transformações, não há justificativa para definir um protocolo fundamentado no transtorno mental. Questionar o protocolo, nos termos em que vem sendo implementado, é encarar a questão da patologização do gênero e colocá-lo na arena dos debates, situando-o como categoria científica, por isso mesmo histórica, o que significa considerar também o seu caráter político. ${ }^{69}$

Portanto a patologização anula a condição dos transexuais de parceiros nas interações sociais, sendo mais pertinentes os protocolos alternativos que atribuem a esses grupos o papel de protagonistas capazes de participar de maneira paritária no espaço público. Tal práxis discursiva das identidades trans, em nível transnacional, pode ser elucidada a partir do referencial teórico elaborado por

68 BENTO, Berenice; PELÚCIO, Larissa. Despatologização do gênero: a politização das identidades abjetas. Estudos Feministas, 20 (2), Florianópolis, 2012, p.576.

69 BENTO, Berenice; PELÚCIO, Larissa. Despatologização do gênero: a politização das identidades abjetas. Estudos Feministas, 20 (2), Florianópolis, 2012, p.576. 
Fraser. Nesse sentido, em Scales of Justice ${ }^{70}$, ao desenvolver a terceira dimensão a esfera do político -, também afirma que ela está conectada às outras, pois não se reduz à redistribuição e ao reconhecimento. Nesse ponto, passa a defender a perspectiva tridimensional de justiça, que trata sobre o reconhecimento, a redistribuição e a esfera do político.

Contudo a terceira dimensão da justiça também visa explicar as injustiças no plano metapolítico/global, as quais surgem quando se realiza a divisão do espaço político em sociedades delimitadas territorialmente. O resultado é uma delimitação injusta da possibilidade de reivindicação das questões de primeira ordem - distribuição, reconhecimento e representação -, inspirando injustiças de mau enquadramento. Nesse âmbito, Fraser exemplifica como injustiça, em nível transnacional, a globalização da pobreza, que ultrapassa as fronteiras territoriais. ${ }^{71}$

Na próxima etapa do estudo, passa-se a investigar a jurisprudência do STJ sobre transexualidade à luz do diálogo Butler-Fraser.

\section{A JURISPRUDÊNCIA DO STJ SOBRE TRANSEXUALIDADE: UMA REFLEXÃO SOBRE OS DESAFIOS DA DESPATOLOGIZAÇÃO E DA CRÍTICA AO BINARISMO À LUZ DO DEBATE BUTLER-FRASER}

O movimento trans tem denunciado as inconsistências e as contradições das normas brasileiras que estabelecem o atendimento à saúde por transexuais. Sustenta a necessidade de substituição do termo "transgenitalismo", a diminuição do requisito da idade para a realização das cirurgias de 21 para 18 anos e a retirada da exigência de dois anos de acompanhamento prévio. O Conselho Federal de Psicologia lançou, em 2014, uma campanha em apoio à luta pela despatologização das identidades trans e travestis. A proposta foi polemizar discursos e práticas patologizantes decorrentes de uma estrutura binária que estabelece processos de exclusão e estigmatização das identidades trans. Mas a questão é: como perceber discursos patologizantes implícitos aos votos de Ministros do STJ?

70 FRASER, Nancy. Scales of Justice: Reimagining Political Space in Globalizing World. New York: Columbia University Press, 2010.

71 FRASER, Nancy. Scales of Justice: Reimagining Political Space in Globalizing World. New York: Columbia University Press, 2010, p. 6. 
No deferimento do pedido de homologação da Sentença Estrangeira n.01058, o STJ determinou a retificação do registro para atribuir sexo e prenome feminino a determinado transexual. $\mathrm{O}$ autor da ação ajuizou pedido de homologação de sentença estrangeira formulada pelo Tribunal de Gênova, na Itália, que estabeleceu a retificação do prenome e do sexo no registro civil, após a realização de cirurgia para mudança de sexo.

Nesse cenário, o Ministro-Presidente Barros Monteiro citou um acórdão paradigmático proferido pelo Tribunal de Justiça de São Paulo na Apelação Civil n. 165.157-4/5, em que o Relator, Desembargador Boris Kaufmann, leciona que "[...] manter-se um ser amorfo, por um lado mulher, psíquica e anatomicamente reajustada, e por outro lado homem, juridicamente, em nada contribuiria para a preservação da ordem social e da moral [...]." Nessa seara, vale a pena transcrever uma passagem do voto do Ministro Dr. Barros Monteiro, que anuncia que:

Já na Declaração Universal dos Direitos de Homem, adotada e proclamada pela Resolução 217 A (III) da Assembléia Geral das Nações Unidas em 10 de dezembro de 1948, afirmava-se que a dignidade é inerente a todos os membros da família humana. E a Constituição em vigor inclui, entre os direitos individuais, a inviolabilidade da intimidade, da vida privada, da honra e da imagem das pessoas (art. $5^{\circ} \mathrm{X}$ ). Reside aqui o fundamento autorizador da mudança do sexo jurídico, pois, sem ela, ofendida estará a intimidade do autor, bem como sua honra. O constrangimento, a cada vez que se identifica, afastou o autor de atos absolutamente normais em qualquer indivíduo, pelo medo da chacota. A busca da felicidade, que é direito de qualquer ser humano, acabou comprometida. ${ }^{72}$

No contexto, o Ministro Barros Monteiro ponderou que a pretensão não ofende a soberania, a ordem pública ou os bons costumes, e que é fundamental conferir ao interessado "[...] uma identidade de gênero que lhe permita resolver a grave dicotomia em sua personalidade, com a possibilidade de garantir-lhe uma vida mais serena e de favorecer a sua integração social em sintonia com sua tendência natural." ${ }^{\prime 3}$ Verifica-se, por meio da leitura do voto do Ministro Barros 72 BRASIL. Superior Tribunal de Justiça. Presidência. Sentença Estrangeira n. 001058. Voto do Relator, Min. Barros Monteiro. Brasília-DF, DJ 04.12.2006a. Disponível em: <www.stj. gov.br>. Acesso em: 04.10.2009.

73 BRASIL. Superior Tribunal de Justiça. Presidência. Sentença Estrangeira n. 001058. Voto do Relator, Min. Barros Monteiro. Brasília-DF, DJ 04.12.2006a. Disponível em: <www.stj. gov.br>. Acesso em: 04.10.2009. 
Monteiro, que, apesar de o próprio compreender que a pretensão não ofende a ordem pública, ao se referir a uma "grave dicotomia em sua personalidade", subentende um discurso implícito baseado em uma compreensão patologizante da transexualidade com potencial estigmatizante.

Diante da referida estrutura conceitual, o aporte teórico amparado por Butler é essencial para compreender um conjunto de discursos implícitos ao teor do voto do Ministro Barros Monteiro, já que a estudiosa defende que as reivindicações de despatologização da transexualidade pressupõem uma demanda mais profunda pela despatologização do gênero, tendo em vista a atuação proeminente das mulheres trans na tematização e na criação de arenas discursivas renovadas em esferas de debate que tradicionalmente eram atribuídas a mulheres com vagina desde o seu nascimento. De outro lado, o teor do voto, ao pressupor uma interpretação patologizante da sexualidade, anula o status dos transexuais como parceiros em interações sociais - o que minimiza a norma da paridade de participação, tal como formula Fraser.

Com efeito, no processo de homologação da Sentença Estrangeira n. 00214974, o mesmo Ministro-Relator Barros Monteiro também deferiu o processo de homologação com base nos mesmos argumentos. Nos processos relativos às Sentenças Estrangeiras n. $004179{ }^{75}$ e n. $002732^{76}$, ambas julgadas em sete de abril de 2009, o Ministro-Relator César Asfor Rocha também deferiu o pedido de homologação, mas determinou que ficasse consignada às margens do registro civil do requerente a observação de que as modificações do nome e do sexo decorrem de decisão judicial.

É mister frisar que o Ministro Marcos Buzzi, no julgamento do RESP n. 1.043.004/RS, deu provimento parcial ao Recurso Especial, a fim de determinar

74 BRASIL. Superior Tribunal de Justiça. Presidência. Sentença Estrangeira n. 2149. Voto do Relator, Min. Barros Monteiro. Brasília-DF, j. em 01.08.2006b. Disponível em: <www.stj. gov.br> Acesso em: 04.10.2009.

75 BRASIL. Superior Tribunal de Justiça. Sentença Estrangeira n. 4.179. Voto do Relator Min. César Asfor Rocha. Brasília-DF, j. em 07.04.2009a. Disponível em: <www.stj.gov.br>. Acesso em: 04.10.2009.

76 BRASIL. Superior Tribunal de Justiça. Sentença Estrangeira n. 002732. Voto do Relator Min. César Asfor Rocha. Brasília-DF, j. em 07.04.2009b. Disponível em: <www.stj.gov.br> Acesso em 4/10/2009. 
a modificação no registro de sexo e prenome, autorizando a averbação, apenas no livro cartorário e à margem do registro, de que a retificação do prenome e do sexo é oriunda de decisão judicial, vedando qualquer menção a este fato nas certidões do registro público. ${ }^{77}$

Por fim, no julgamento do Recurso Especial n. 1008398/SP 78, a Terceira Turma do STJ, por unanimidade, deu-lhe provimento em quinze de outubro de 2009, nos termos do voto da Relatora, Ministra Nancy Andrighi, deferindo a alteração de prenome e de sexo de transexual redesignado, com base no princípio da dignidade da pessoa humana. A Ministra-Relatora profere que

[...] conservar o sexo masculino no assento de nascimento do recorrente, em favor da realidade biológica e em detrimento das realidades psicológica e social, bem como morfológica, pois a aparência do transexual redesignado, em tudo se assemelha ao sexo feminino, equivaleria a manter o recorrente em estado de anomalia, deixando de reconhecer seu direito de viver dignamente. [...]. ${ }^{79}$

Nessa linha de raciocínio, o voto da Ministra Nancy Andrigui, ao se referir às realidades psicológica e social do transexual, assim como à necessidade de não manter o recorrente em estado de anomalia, representa avanço na jurisprudência brasileira, no que tange à superação da concepção patologizante de transexualidade. Todavia, quando a Ministra pondera que "[...] a aparência do transexual redesignado em tudo se assemelha ao sexo feminino" 80 , ainda pressupõe uma concepção binária de sexo, que é problematizada tanto por Butler como por Fraser.

Trata-se de uma estrutura sexual binária que, na perspectiva de Butler, seria decorrente da regra da heteronormatividade. As categorias identitárias, portanto, 77 BRASIL. Superior Tribunal de Justiça. Recurso Especial n. 1.043.004. Voto do Ministro Marcos Buzzi. Brasília-DF, j. em 1/08/2013. Disponível em: <www.stj.gov.br> Acesso em 4/10/2015.

78 BRASIL, Superior Tribunal de Justiça. Terceira turma. Recurso Especial n. 1.008.398/SP. Voto da Relatora, Ministra Nancy Andrighi. Brasília-DF, j. 15.10.2009c. Disponível em: <www. stj.gov.br>. Acesso em: 04.10.2010.

79 BRASIL, Superior Tribunal de Justiça. Terceira turma. Recurso Especial n. 1.008.398/SP. Voto da Relatora, Ministra Nancy Andrighi. Brasília-DF, j. 15.10.2009c. Disponível em: <www. stj.gov.br>. Acesso em: 04.10.2010.

80 BRASIL, Superior Tribunal de Justiça. Terceira turma. Recurso Especial n. 1.008.398/SP. Voto da Relatora, Ministra Nancy Andrighi. Brasília-DF, j. 15.10.2009c. Disponível em: <www. stj.gov.br>. Acesso em: 04.10.2010. 
para a teórica, são produtos ficcionais das estruturas de poder, ou seja, no sentido de que não são preexistentes às estruturas de poder, sendo produtos performativos das instituições, das práticas e dos discursos.

Como já se salientou, para Butler ${ }^{81}$, os atributos biológicos não resumem uma base coerente para fundamentar a identidade, porquanto sexo e gênero são construções socioculturais que pressupõem as aspirações dos sujeitos de se ajustarem a padrões sociais. Portanto a decisão reflete implicitamente um discurso que incorpora um conjunto de categorias aparentemente fundacionais, mas que são produtos culturais capazes de criar uma aparência de natural, original, inevitável. Nesse ponto de vista, Jagger interpreta que, para Butler, categorias identitárias são "[...] efeitos performativos da linguagem e significação, ao invés de propriedades dos indivíduos, ou expressão linguística do natural, baseadas na materialidade do corpo."82

Segundo Jagger, Butler não estabelece como estratégia teórica apenas a análise da desnaturalização das categorias identitárias, mas também trata da possibilidade de resistência e de mudança no âmbito das mesmas. Uma vez que o sistema binário de diferença sexual é uma estrutura instável, surge assim a possibilidade de transformação. Com efeito, o projeto político torna-se uma questão de subversão da identidade..$^{83}$

Fraser ${ }^{84}$, por sua vez, pela crítica aos remédios afirmativos, se contrapõe ao binarismo homem-mulher (ou hetero-homo), procurando desestabilizar o sistema binário de diferenciação sexual que foi expresso, por exemplo, no discurso implícito ao voto da decisão da Ministra Nancy Andrigui no RESP n 1008398/SP. ${ }^{85}$ O reconhecimento afirmativo, voltado para reparar a injustiça contra homossexuais e transexuais na cultura, engloba a valorização da cultura LGBT, mas inspira uma

81 BUTLER, Judith. Problemas de Gênero: Feminismo e Subversão da Identidade. Rio de Janeiro: Civilização Brasileira, 2003.

82 JAGger, Gill. Sexual Politics, Social Change and the Power of Performative. New York: Routledge, 2008, p. 8.

83 JAGGER, Gill. Sexual politics, Social Change and the Power of Performative. New York: Routledge, 2008, p. 8.

84 FRASER, Nancy. Da redistribuição ao reconhecimento? Dilemas da justiça na era pós-socialista. In: SOUZA, Jessé (Org). Democracia Hoje. Novos desafios para a teoria democrática contemporânea. Brasília: Editora UNB, 2001.

85 BRASIL, Superior Tribunal de Justiça. Terceira turma. Recurso Especial n. 1.008.398/SP. Voto da Relatora, Ministra Nancy Andrighi. Brasília-DF, j. 15.10.2009c. Disponível em: <www. stj.gov.br>. Acesso em: 04.10.2010. 
reificação identitária, enquanto deixa intacto o código binário homem-mulher que atribui sentido à relação. Assim, a decisão da Ministra contém implicitamente discursos que refletem remédios afirmativos - tão criticados por Fraser.

Portanto, sustenta-se, à luz de Fraser ${ }^{86}$ que, embora Butler (1997b) teorize um relevante diagnóstico da opressão contra minorias que permite compreender (ainda que de forma parcial) o discurso implícito ao voto da Ministra Nancy Andrigui no julgamento supracitado, sua perspectiva é insuscetível de justificar a motivação da crítica porquanto a ideia de identidade não atinge o fim de superar a exclusão.

Nessa perspectiva, Fraser ${ }^{87}$ possui recursos conceituais que revelam maior alcance teórico para interpretar o julgamento do RESP n 1008398/SP88, uma vez que sustenta uma teoria feminista que se opõe à essencialização identitária e ao binarismo de gênero, sem, porém, anular a autonomia do sujeito, assumindo como objetivos a descrição das desigualdades e a formulação de um projeto emancipatório, por meio de contrapúblicos subalternos. Aqui, o referencial teórico de Fraser é democraticamente informado, pressupondo uma crítica ao binarismo sexual que é, ao mesmo tempo, situada e autorreflexiva, oportunizando compreender criticamente o teor do verdadeiro sentido do julgamento do RESP n. 1008398/SP. ${ }^{89}$

Postula-se, à luz de Fraser, que a estrutura conceitual delineada por Butler - no sentido de que a reificação da performatividade é negativa, enquanto a desreificação é positiva - não atende aos objetivos emancipatórios do feminismo. Nas palavras de Fraser, "Butler tem explicitamente renunciado a recursos morais teóricos necessários para a concepção de seus próprios julgamentos normativos implícitos." ${ }^{\prime 90}$

86 FRASER, Nancy. Heterosexism, misrecognition and capitalism: a response to Judith Butler. New Left Review, London, n. 228, 1998, p. 140-149.

87 FRASER, Nancy. Heterosexism, misrecognition and capitalism: a response to Judith Butler. New Left Review, London, n. 228, 1998, p. 140-149.

88 BRASIL, Superior Tribunal de Justiça. Terceira turma. Recurso Especial n. 1.008.398/SP. Voto da Relatora, Ministra Nancy Andrighi. Brasília-DF, j. 15.10.2009c. Disponível em: <www. stj.gov.br>. Acesso em: 04.10.2010.

89 BRASIL, Superior Tribunal de Justiça. Terceira turma. Recurso Especial n. 1.008.398/SP. Voto da Relatora, Ministra Nancy Andrighi. Brasília-DF, j. 15.10.2009c. Disponível em: <www. stj.gov.br>. Acesso em: 04.10.2010.

90 FRASER, Nancy. Fortunes of Feminism. From State Maneged Capitalism to Neoliberal Crisis. London: Verso, 2014, p. 162. 
Recentemente, em Fortunes of Feminism, Fraser infere que a política feminista exige "[...] uma visão político-moral mais compreensiva que a desreificação da performatividade." ${ }^{\prime 11}$ Assim, surge a questão: a reflexão da Butler assume uma dimensão política? Teriam a paródia ou drag alternativas ao efetivo alcance e impacto político para certos grupos de mulheres oprimidas? Nesse ponto, sustenta-se que as teorias de Butler e Fraser se complementam, pois Butler acerta no diagnóstico, enquanto Fraser estabelece uma teoria da democracia mais ampla que conduz à superação efetiva da subordinação de status. Segundo Fraser, o projeto político de Butler é enfraquecido e não explica por que certas formas de subversão são positivas, enquanto outras não são.

Com isso, defende-se que a desconstrução discursiva da concepção binária de gênero presente e a superação da interpretação patologizante - no que concerne à moldura adequada de justiça - devem, à luz do referencial teórico de Fraser, satisfazer à dimensão da representação e contar com o assentimento de todos os concernidos a um processo de deliberação que seja justo e aberto. Ademais, tal desconstrução deve estar atenta às experiências internacionais de concretização de direitos humanos relativos a demandas identitárias de transexuais, pois, como preconiza Fraser ${ }^{92}$, o princípio de todos os afetados não coincide necessariamente com o princípio do Estado territorial. Nesse âmbito, emerge, no cenário internacional, a campanha Stop Trans Patologization, articulada por ativistas queer, que consideram os gêneros como categorias instáveis e plurais.

No quadro teórico que se deslinda, percebe-se a relevância do pensamento de Fraser, a partir do qual se pode visualizar como a discussão atual sobre o quem da temática da transexualidade ultrapassa a moldura keynesiana-westfaliana dos públicos nacionais. As demandas por reconhecimento reivindicadas por transexuais cada vez mais ultrapassam os limites do Estado nacional, visto que os reivindicantes não se restringem a problematizar temáticas relativas apenas às relações entre cidadãos e Estado.

91 FRASER, Nancy. Fortunes of Feminism. From State Maneged Capitalism to Neoliberal Crisis. London: Verso, 2014, p. 163.

92 FRASER, Nancy. Scales of Justice: Reimagining Political Space in Globalizing World. New York: Columbia University Press, 2010. 
Dessa feita, segundo Fraser ${ }^{93}$, os movimentos sociais, ao reivindicarem o direito de determinar o quem, problematizam o como hegemônico, tematizando a criação de procedimentos novos e não hegemônicos relativos a disputas de enquadramento de justiça. Tal questão pode ser exemplificada na questão da discussão sobre a transexualidade, no que se refere ao quem destinatário de tais benefícios e em relação a quais critérios para a definição do quem.

\section{CONSIDERAÇÕES FINAIS}

Diante do exposto, sustenta-se que a crítica de Butler quanto à diferenciação dicotômica entre reconhecimento e redistribuição minimiza um aspecto central da teoria de Fraser. Trata-se de dimensões distintas, mas interconectadas, requerendo tal distinção analítica para estabelecer os remédios adequados para cada tipo de injustiça. Segundo Fraser ${ }^{94}$, Butler confunde o dualismo entre classe e status com um monismo economicista ligado a uma tradição neomarxista conservadora.

Defende-se, com base no posicionamento de Fraser, que ambas as injustiças são importantes, não sendo necessário provar que o não reconhecimento implica má distribuição para caracterizar uma situação de injustiça. Em suma, as lutas por reconhecimento não precisam demonstrar que constituem uma ameaça ao capitalismo para adquirirem o status de lutas justas. As injustiças que decorrem do não reconhecimento são igualmente graves - como as injustiças distributivas - e os danos culturais não são reflexos superestruturais das injustiças econômicas.

De fato, para concretizar os direitos fundamentais de transexuais, é fundamental resgatar as perspectivas teóricas de Butler e Fraser. Sustenta-se que as teorias das autoras se complementam, porquanto a primeira acerta no diagnóstico, enquanto Fraser desenvolve uma teoria democraticamente informada baseada na ideia de contrapúblicos subalternos. Tal modelo permite desconstruir mecanismos institucionais na esfera da distribuição, do reconhecimento e da representação,

93 FRASER, Nancy. Scales of Justice: Reimagining Political Space in Globalizing World. New York: Columbia University Press, 2010.

94 FRASER, Nancy. False Antitheses: a response to Seyla Benhabib and Judith Butler. In: FRASER, Nancy. Justice Interruptus: Critical Reflections on the Postsocialist Condition. New York: Routledge, 1997. 
os quais impedem uma participação efetiva de transexuais como pares nas interações sociais do espaço público - daí a relevância da ideia de contrapúblicos subalternos -, o que potencializa a desconstrução da dicotomia hetero-homo e desestabiliza todas as identidades sexuais.

Torna-se imprescindível "[...] nomear 'patologização do gênero' em vez de 'psiquiatrização do gênero', por entendermos que há um conjunto de saberes polimorfos que se articulam para produzir as normas e os normais de gênero." ${ }^{195} \mathrm{Em}$ resumo, nas reivindicações de despatologização da transexualidade, surge, com fundamentação em Butler ${ }^{96}$, uma demanda mais profunda pela despatologização do gênero, tendo em vista a atuação proeminente das mulheres trans na tematização e na criação de arenas discursivas renovadas em esferas de debate que tradicionalmente eram atribuídas a mulheres com vagina desde o seu nascimento.

Nesse horizonte, o referencial de Butler é relevante para investigar as estruturas de poder do próprio sujeito do feminismo. Para Butler ${ }^{97}$, o sujeito abarca uma questão crucial para a política feminista, pois os sujeitos jurídicos são produzidos por via de práticas de exclusão que não aparecem, uma vez estabelecida a estrutura jurídica da política. Não obstante, a perspectiva de Fraser revela maior alcance teórico para interpretar o julgamento do RESP n. 1008398/SP98, porquanto, embora também pressuponha uma perspectiva desconstrutiva, não anula a autonomia do sujeito, incorporando uma crítica situada e autorreflexiva que desmascara o discurso implícito ao julgamento do RESP n. 1008398/SP99, de conteúdo ainda voltado à consagração da estrutura binária.

Na ponderação de Fraser, embora o antiessencialismo tenha a virtude de teorizar as identidades como discursivamente construídas - e não como algo 95 BENTO, Berenice; PELÚCIO, Larissa. Despatologização do gênero: a politização das identidades abjetas. Estudos Feministas, 20 (2), Florianópolis, 2012, p.575.

96 BUTLER, Judith. Problemas de Gênero: Feminismo e Subversão da Identidade. Rio de Janeiro: Civilização Brasileira, 2003.

97 BUTLER, Judith. Problemas de Gênero: Feminismo e Subversão da Identidade. Rio de Janeiro: Civilização Brasileira, 2003.

98 BRASIL, Superior Tribunal de Justiça. Terceira turma. Recurso Especial n. 1.008.398/SP. Voto da Relatora, Ministra Nancy Andrighi. Brasília-DF, j. 15.10.2009c. Disponível em: <www. stj.gov.br>. Acesso em: 04.10.2010.

99 BRASIL, Superior Tribunal de Justiça. Terceira turma. Recurso Especial n. 1.008.398/SP. Voto da Relatora, Ministra Nancy Andrighi. Brasília-DF, j. 15.10.2009c. Disponível em: <www. stj.gov.br>. Acesso em: 04.10.2010. 
objetivamente dado -, a política da versão desconstrutiva é simplista. Transfobia e binarismo não podem ser desmantelados por práticas desconstrutivas exclusivamente. A não essencialização e a desconstrução identitária representam um pressuposto para se vislumbrar uma multiplicidade de relações sociais que devem ser contempladas por uma democracia radical.

Entretanto éjustamente nas arenas discursivas estabelecidas pelos contrapúblicos subalternos que os transexuais têm articulado, de forma mais renovada, a compreensão acerca de sua realidade, no que diz respeito à discussão de temas relacionados à violência, à despatologização, à transfobia, à mudança de prenome, minimizando a profunda situação de desvantagem na esfera pública oficial.

Em síntese, sustenta-se que o instrumental teórico de Fraser ${ }^{100}$ é significativo para a compreensão de formas de judicialização que protegem direitos de transexuais, pois, de um lado, permite combater as assimetrias econômicas entre as minorias sexuais, ampliando as possibilidades de acesso dos transexuais no mercado de trabalho. De outro lado, a concepção de contrapúblicos subalternos possibilita ao movimento transexual desconstruir concepção binária de gênero do Ocidente, o alinhamento automático entre sexo anatômico e identidade sexual e a interpretação patologizante da transexualidade.

Nessa trajetória teórica, defende-se, com base em Fraser, a necessidade de desestabilizar as identidades sexuais, o que poderia se concretizar por meio da existência de contrapúblicos subalternos que permitem circulação de discursos de oposição de identidades trans excluídas da esfera pública oficial.

Indubitavelmente, o Movimento LGBT no Brasil, por meio de procedimentos não hegemônicos, tem discutido sobre os critérios para a definição do quem, o que evidencia a importância da dimensão da representação, tal como descreve Fraser. No entanto, apesar das conquistas de gays e lésbicas no cenário nacional, em relação aos transexuais, ainda se apura deficit de sua representação nos espaços políticos nacionais.

Justamente para suprir esse deficit recentemente, vê-se um considerável 100 FRASER, Nancy. Justice Social in the Age of Identity Politics. In: FRASER, Nancy; HONNETH, Axel. Redistribution or Recognition? - A Political Philosophical Exchange. London: Verso, 2003b. 
processo de transnacionalização do movimento trans, por meio de conexões e de redes discursivas que não se situam em territórios geograficamente delimitados. De fato, o estabelecimento de redes transnacionais entre o Movimento Transexual pode potencializar a construção de interpretações antiessencialistas capazes de romper com os discursos patologizantes e seus efeitos estigmatizantes em uma perspectiva que articula o local e o global.

Sob essa ótica, estruturado na teoria de Fraser, propugna-se que o objetivo emancipatório da Teoria Crítica diz respeito à compreensão de que todos os afetados devem ter iguais chances de se engajar em lutas participativas na esfera pública para definir o que conta como reconhecimento. A questão é: "[...] alguns deles foram excluídos ou marginalizados como consequência de um arranjo social injusto?"101 Assim, configura o papel da teoria crítica identificar os impedimentos à justa contestação sobre o significado do reconhecimento.

Com efeito, para superar o preconceito transfóbico, é necessário corrigir o deficit de representação política de transexuais nas instâncias de poder - razão pela qual se reconhece a relevância do novo modelo teórico tridimensional de Fraser (2010) para a análise dos desafios propostos pelas demandas dos grupos LGBT. O deficit de representação de minorias sexuais não hegemônicas nos espaços de representação política nacional ainda simboliza uma herança da sociedade heterossexista e transfóbica que impede a construção de uma democracia plena no Brasil.

A ideia é superar a subordinação e não essencializar a identidade, no sentido da desinstitucionalização de padrões de valores culturais que impedem a paridade de participação de certos atores sociais. No Brasil, Berenice Bento vem analisando a patologização da identidade como um instrumento para a patologização do próprio gênero. À medida que se assume o gênero como categoria nosológica, se oculta a norma disciplinar da heteronormatividade.

Sob esse prisma, conclui-se que não basta que transexuais sejam considerados minorias-alvo de políticas de saúde. É fundamental, pois, que sejam protagonistas de uma criação democrática de políticas públicas voltadas para a desconstrução 101 FRASER, Nancy. Prioritizing Justice as Participatory Parity: a reply to Kompridis and Forst. In: OLSON, Kevin. Adding Insult to Injury. Nancy Fraser debates her critics. London: Verso, 2008, p. 331-332. 
de padrões hierárquicos de valores culturais relacionados a uma concepção patologizante de transexualidade e ao binarismo de gênero. Finalmente, somente uma perspectiva desconstrutiva proposta por Fraser pode resguardar direitos de minorias sexuais não hegemônicas, inspirando a transformação social e a ruptura com as normas assimétricas de mundo.

\section{REFERÊNCIAS}

BELTRAN, Soley. Transexualidad y la Matriz Heterosexual: un Estudio Critico de Judith Butler. Barcelona: Belaterra, 2009.

BENTO, Berenice e PELÚCIO, Larissa. Despatologização do gênero: a politização das identidades abjetas. Estudos Feministas, 20 (2), Florianópolis, 2012, p.569-581.

BRASIL. Superior Tribunal de Justiça. Presidência. Sentença Estrangeira n. 001058. Voto do Relator, Min. Barros Monteiro. Brasília-DF, DJ 04.12.2006a. Disponível em: <www.stj.gov.br>. Acesso em: 04.10.2009.

BRASIL. Superior Tribunal de Justiça. Presidência. Sentença Estrangeira 2149. Voto do Relator, Min. Barros Monteiro. Brasília-DF, j. em 01.08.2006b. Disponível em: <www.stj.gov.br> Acesso em: 04.10.2009.

BRASIL. Superior Tribunal de Justiça. Presidência. Sentença Estrangeira 4.179. Voto do Relator Min. César Asfor Rocha. Brasília-DF, j. em 07.04.2009a. Disponível em: <www.stj.gov. br>. Acesso em: 04.10.2009.

BRASIL. Superior Tribunal de Justiça. Presidência. Sentença Estrangeira 002732. Voto do Relator Min. César Asfor Rocha. Brasília-DF, j. em 07.04.2009b. Disponível em: <www.stj.gov. br> Acesso em: 4/10/2009.

BRASIL, Superior Tribunal de Justiça. Terceira turma. Recurso Especial n. 1.008.398/SP. Voto da Relatora, Ministra Nancy Andrighi. Brasília-DF, j. 15.10.2009c. Disponível em: <www.stj.gov.br>. Acesso em: 04.10.2010.

BRASIL. Superior Tribunal de Justiça. Recurso Especial n. 1.043.004. Voto do Ministro Marcos Buzzi. Brasília-DF, j. em 1/08/2013. Disponível em: <www.stj.gov.br> Acesso em 4/10/2015.

BUTLER, Judith. The Psychic Life of Power. Theories in Subjection.Standford, CA: Standford University Press, 1997a 
BUTLER, Judith. Merely Cultural. Social Text, 52-53 (1997b), p. 265-77.

BUTLER, Judith. Problemas de Gênero: Feminismo e Subversão da Identidade. Rio de Janeiro: Civilização Brasileira, 2003.

BUTLER, Judith. Problemas de Gênero: Feminismo e Subversão da Identidade. Rio de Janeiro: Civilização Brasileira, 2015.

CHAMBOULEYROUN, Ingrid Cyfer. A tensão entre Modernidade e Pós-modernidade na Crítica à Exclusão no Feminismo. Tese. (Doutorado em Ciência Política) Faculdade de Filosofia, Letras e Ciências Humanas. Universidade de São Paulo, 2009.

FRASER, Nancy. Unruly Practices: Power, Discourse and Gender in Contemporary Social Theory. Minneapolis: University of Minnesota Press, 1989.

FRASER, Nancy. Prioritizing Justice as Participatory Parity: a reply to Kompridis and Forst. In: OLSON, Kevin. Adding Insult to Injury. Nancy Fraser debates her critics. London: Verso, 2008, p. 327-347.

FRASER, Nancy. Rethinking the Public Sphere: a Contribution to the Critique of Actually Existing Democracy. In: CALHOUN, Craig. Habermas and the Public Sphere. Cambridge: Mit Press, 1992.

FRASER, Nancy. What's Critical about Critical Theory? In: MEEHAN, Johann (Ed.). Feminist Read Habermas: Gendering the Subject of Discourse. New York: Routledge, 1995.

FRASER, Nancy. False Antitheses: a response toSeylaBenhabiband Judith Butler. In: FRASER, Nancy. Justice Interruptus: Critical Reflections on the Postsocialist Condition. Routledge: New York, 1997.

FRASER, Nancy. Heterosexism, misrecognition and capitalism: a response to Judith Butler. New Left Review, London, n. 228, 1998, p. 140-149.

FRASER, Nancy. Recognition without Ethics? In: Theory, Culture \& Society, London, vol. 18, n. 2-3, 2001.

FRASER, Nancy. Da redistribuição ao reconhecimento? Dilemas da justiça na era póssocialista. In: SOUZA, Jessé (Org). Democracia Hoje. Novos desafios para a teoria democrática contemporânea. Brasília: Editora UNB, 2001.

FRASER, Nancy. Distorted Beyound all Recognition: A Rejoinder to Axel Honneth.In: FRASER, Nancy; HONNETH, Axel. Redistribution or Recognition? - A Political Philosophical Exchange. London: Verso, 2003. 
FRASER, Nancy. Justice Social in the Age of Identity Politics. In: FRASER, Nancy; HONNETH, Axel. Redistribution or Recognition? A Political Philosophical Exchange. London: Verso, 2003.

FRASER, Nancy. Repensando a questão do reconhecimento: superar a substituição e a reificação na política cultural. In: BALDI, César Augusto (org). Direitos Humanos na Sociedade Cosmopolita. Rio de Janeiro: Renovar, 2004.

FRASER, Nancy. Scales of Justice: Reimagining Political Space in Globalizing World. New York: Columbia University Press, 2010.

FRASER, Nancy. Fortunes of Feminism. From State Maneged Capitalism to Neoliberal Crisis. London: Verso, 2014.

FREUD, Sigmund. Luto e Melancolia. São Paulo: Cosac Naify, 2011.

JAGGER, Gill. Sexual politics, Social Change and the Power of Performative. New York: Routledge, 2008.

RUBIN, Gayle. Notes for a Radical Theory of the Politics of Sexuality. In: VANCE, Carol. Pleasure and Danger: Exploring female sexuality. Boston: Routledge \& K. Paul, 1984.

SALIH, Sara. Judith Butler e a Teoria Queer. Belo Horizonte: Autêntica, 2012.

Recebido em: nov/2015

Aprovado em: dez/2015 